\title{
State, Transnational Citizenship and the Transformative Power of Art: The NSK State in Time
}

\author{
Barbara Orel \\ University of Ljubljana
}

Follow this and additional works at: https://docs.lib.purdue.edu/clcweb

(3)

Part of the Performance Studies Commons

Dedicated to the dissemination of scholarly and professional information, Purdue University Press selects, develops, and distributes quality resources in several key subject areas for which its parent university is famous, including business, technology, health, veterinary medicine, and other selected disciplines in the humanities and sciences.

CLCWeb: Comparative Literature and Culture, the peer-reviewed, full-text, and open-access learned journal in the humanities and social sciences, publishes new scholarship following tenets of the discipline of comparative literature and the field of cultural studies designated as "comparative cultural studies." Publications in the journal are indexed in the Annual Bibliography of English Language and Literature (Chadwyck-Healey), the Arts and Humanities Citation Index (Thomson Reuters ISI), the Humanities Index (Wilson), Humanities International Complete (EBSCO), the International Bibliography of the Modern Language Association of America, and Scopus (Elsevier). The journal is affiliated with the Purdue University Press monograph series of Books in Comparative Cultural Studies. Contact: <clcweb@purdue.edu>

\section{Recommended Citation}

Orel, Barbara. "State, Transnational Citizenship and the Transformative Power of Art: The NSK State in Time." CLCWeb: Comparative Literature and Culture 22.4 (2020): <https://doi.org/10.7771/1481-4374.3388>

This text has been double-blind peer reviewed by $2+1$ experts in the field.

The above text, published by Purdue University Press @Purdue University, has been downloaded 0 times as of 03/14/ 21.

This document has been made available through Purdue e-Pubs, a service of the Purdue University Libraries. Please contact epubs@purdue.edu for additional information.

This is an Open Access journal. This means that it uses a funding model that does not charge readers or their institutions for access. Readers may freely read, download, copy, distribute, print, search, or link to the full texts of articles. This journal is covered under the CC BY-NC-ND license. 


\section{PURDUE}

UNIVERSITY PRESS <http://www.thepress. purdue.edu>

\section{CLCWeb: Comparative Literature and Culture}

ISSN 1481-4374 <http://docs.lib.purdue.edu/clcweb> Purdue University Press @Purdue University

CLCWeb: Comparative Literature and Culture, the peer-reviewed, full-text, and open-access learned journal in the humanities and social sciences, publishes new scholarship following tenets of the discipline of comparative literature and the field of cultural studies designated as "comparative cultural studies." In addition to the publication of articles, the journal publishes review articles of scholarly books and publishes research material in its Library Series. Publications in the journal are indexed in the Annual Bibliography of English Language and Literature (ChadwyckHealey), the Arts and Humanities Citation Index (Thomson Reuters ISI), the Humanities Index (Wilson), Humanities International Complete (EBSCO), the International Bibliography of the Modern Language Association of America, and Scopus (Elsevier). The journal is affiliated with the Purdue University Press monograph series of Books in Comparative Cultural Studies. Contact: <clcweb@purdue.edu>

\section{Volume 22 Issue 4 (December 2020) Article 12 Barbara Orel, "State, Transnational Citizenship and the Transformative Power of Art: The NSK State in Time" <http://docs.lib.purdue.edu/clcweb/vol22/iss4/12>}

Contents of CLCWeb: Comparative Literature and Culture 22.4 (2020) $<$ http://docs.lib.purdue.edu/clcweb/vol22/iss4/>

Abstract: This article deals with one of the most intriguing art projects at the intersection of art and social experiment-The NSK State in Time. This is a paradigmatic transnational state that does not have a territory and whose citizenship can be obtained regardless of one's nationality, citizenship, race, religion or political convictions. It was established in 1992 by the Slovenian art collective Neue Slowenische Kunst-the NSK, and has seen continuous manifestations in various sociopolitical contexts worldwide. The most prominent one in recent time took place in 2017, when the NSK State opened its own pavilion at the Venice Biennale-a nationally conceptualized fine art event-to exhibit its art next to other countries of the world. This case study analyses the development of The NSK State in Time through the 28 years of its existence, shedding light on the state-formative role of culture and art in the shaping of communities and their identities in the globalized world. The author argues that the NSK State has established a utopian political space that has the power of transcending the ideological limitations of the existing (spatial) states. She demonstrates that this transformative power derives from its liminal position and relentless pursuit of in-betweenness as opposed to the social and political order of the localities where the manifestations of the NSK State take place. 


\section{Barbara OREL}

\section{State, Transnational Citizenship and the Transformative Power of Art: The NSK State in Time}

The Neue Slowenische Kunst collective or the NSK was formed in 1984 by three founding groups: the IRWIN visual arts group, the Laibach music band and the Scipion Nasice Sisters' Theatre (for the genealogy of the NSK groups cf. Intihar Ferjan 506-525). Since the early 1980s, the NSK have been developing art as an idea of state, "in which Laibach represented the ideological, the theatre, the religious, and Irwin the cultural and historical impulse. The element shared by all three groups is [...] a tendency towards a formative, not only intellectual and verbal, but also physical analysis of concepts on the basis of which states had been constituted or dismantled through history" (Čufer, "Concepts" 4748). In 1992, the NSK artists formally founded a state and named it The NSK State in Time. For over 28 years, its citizenship has been available to any interested individuals regardless of their nationality, race, religion or political convictions. So far, it has been obtained by approximately 15,000 people including Marina Abramović, Slavoj Žižek, Boris Groys and Hans Ulrich Obrist.

The integration into the NSK State takes place through the ritual procedures of making a person a part of its community, conceived as a non-hierarchical, autonomous and sovereign social structure. The inclusion into this symbolic state takes place through a simple administrative process of passport acquisition: all one needs to do is to fill out the application form (accessible on the NSK State website: https://passport.nsk.si/en/how_to_get_an_NSK_passport), and send in the form with two photographs to the NSK Information Centre in Ljubljana (Slovenia) along with proof of payment of 32 euros. Approximately in five weeks' time, one receives a passport along with NSK citizenship. By signing the adjoining statement, one "pledges to participate on a best-effort basis to support the integrity of the NSK State" ("Frequently"). NSK citizens do not have any other duties to the state, nor are there any concrete benefits to be obtained. The NSK State "has no formal 'government' and no central committee, only citizens, few bureaucrats and some administrators. The last two only deal with technical issues keeping the State formal. It is based on self-management and non-alignment and it coexists as a parasite within existing, already established bodies in the entire area of Time" (Westerman 159-160).

The NSK State in Time does not have a geographical territory and-as its name suggests-exists in the dimension of time. In other words, the territory of this state is defined by the category of time. Advocating the principle of transnationality in all its basic charters, the artists founded the NSK State without observing two fundamental principles that modern states are based on: the principles of territoriality and nationality. They thus rejected the traditional concept of the nation state, offering a postnational or transnational entity that they define as the "first global state of the universe" ("The Official"). The "NSK State in Time" manifesto states: "NSK confers the status of a state not to territory but to the mind, whose borders are in a state of flux in accordance with the movements and changes in its symbolic and physical collective body" (Čufer, "NSK State" 501). The NSK relates the shaping of a state predominantly to the mind, i.e., to the domain of thought and the process of imagining community. It is sensible to base the definition of the NSK citizen community on the concept of imagined community by Benedict Anderson. According to Anderson, imagined community is a result of inventing a community that did not exist before (Anderson 6). The term "community" relates to the conceiving of "a deep, horizontal comradeship" and "fraternity," which connect the individuals. The same is at the core of the NSK State formation: the process of creating a community that did not exist beforehand and is based on the friendship between and brotherhood of its citizens. Introducing the term "imagined community" in 1983 in his book Imagined Communities, Anderson used it to define the concept of nation. It is sensible to define the NSK State in relation to the national community because the creation of the transnational community of the NSK citizens was driven by the necessity to transcend the limitations of the nation state and defy the concept of nation as an obsolete model of existence in the globalized world. According to Anderson, nation "is an imagined political community - and imagined as both inherently limited and sovereign" (6). Nation is imagined as limited in terms of being surrounded by "boundaries, beyond which lie other nations," and it is sovereign since it is driven by the Enlightenment "dream of being free" (7). The NSK State is based on the sovereignty principle, but unlike the concept of nation, it is imagined as a community not limited by national boundaries. Quite the contrary, the NSK State offers the chance of transcending the limitations imposed on citizens of nation states. Before dealing with these issues in more detail, let us examine the historical context of this state's founding.

The initiative to create the NSK State emerged in Slovenia, more precisely, amongst the Slovenian artists with the experience of living in the Socialist Federal Republic of Yugoslavia (Slovenia used to be part of Yugoslavia until 1991, when it proclaimed independence and established itself as an independent state). The founding of the NSK State (1992) can be interpreted as a reaction to the historical conditions 
in post-1989 Europe and the disintegration of the Eastern European socialist regimes, which gave rise to new states, including Slovenia. This was a time of an intense fragmentation of the European political space in the post-communist condition, marked by nation-state tendencies and increased nationalisms on the one hand and transnational idealism on the other. The NSK state is a result of the specific cultural and historical conditions in Slovenia after the fall of the Berlin Wall. According to the "Cari amici" manifesto from 1993, when the NSK State was first presented at the Venice Biennale, the NSK State was formed out of

[...] the need to find completely new (political and aesthetic) organizational forms in order to create a dynamic system of matrixes, that is to say 'packaging', in order to establish an ostensible 'new world order' - a world in which the nation-state will have become a dangerous anachronism, and in which the idea of a dominant globalism is useless to regions with suppressed national identities due to its ideology of forcible universalism. ("Cari amici" 12-13)

These are the main reasons why the NSK collective founded "its own modus vivendi, its own pavilion and its own state" (ibid.).

Many interpreted the founding of the NSK State as a reaction to the disintegration of Yugoslavia. Nevertheless, the primary aim of the NSK collective was to respond to the founding of Slovenia. As a group that used to provocatively play with elements of the Slovenian national identity (which is already evident from its German name: Neue Slowenische Kunst means New Slovenian Art), the NSK collective could have potentially lost its radical stance and subversive power in the new social context. Alexei Monroe finds that, with the Slovenian independence, "the NSK faced the threat of a moment of nationalist closure in which its difference and ambiguity would evaporate, and be smoothly conscripted into the narratives of the new state" (252).

Throughout its existence, the NSK collective has strived to take an alternative position towards the existing social, cultural and political conditions. In the early 1990 s, they recognized an alternative stance in inventing their own state. In this, they strived for in-betweenness in terms of Victor Turner's concept of liminality. By founding their own state, they presented a realm for a new mode of existence and human interrelations-in terms of what Turner defines as a communitas and introduces it into the regular structure of society. It is characterized as "an unstructured or rudimentarily structured and relatively undifferentiated comitatus" (Turner 96). Compared to regular society, which is a "differentiated, and often hierarchical system of politico-legal-economic positions with many types of evaluation" (96), the NSK State exists in the dimension of in-betweenness. It is "neither here nor there," "in and out of time," as Victor Turner would put it. What we are dealing with are two intertwining systems of social relations. It is precisely this liminal position that gives transformative power to this artistic project and social event. The subversive potential to transcend the limitations faced by nation state citizens in a globalized world lies in the NSK State's constant striving to be "betwixt and between the positions assigned and arrayed by law, custom, convention, and ceremonial" (Turner 95). This position enables it to abolish the rules governing the regular structure of society, and to give rise to disorientation and unstructured experience of all the participants, which can lead to change.

The NSK State manifested every time when the NSK groups collectively organized artistic and other events (exhibitions, performances, concerts, lectures, conferences etc.). For the duration of these events, their venues were declared "embassies" and "consulates" of the NSK, and bore its state symbols - the NSK flag and coat of arms (designed by the IRWIN visual arts group). These artistic events thus took over the form of diplomatic activities and citizenship practices. The first manifestation of the NSK State, NSK Embassy Moscow, took place between 10th May and 10th June 1992 in a Moscow private apartment located at Leninsky Prospekt 12. It was conceived as a live installation of NSK documents, artworks by IRWIN, theatrical events by the Noordung Cosmo-kinetic Cabinet (the theatre group that replaced the Scipion Nasice Sisters' Theatre, again led by the director Dragan Živadinov). The installation was accompanied by a scientific meeting-a one-week program of lectures and discussions attended by renowned Slovenian and Russian scholars and researchers (the philosophers Rastko Močnik and Marina Gržinić and the theatre director and theorist Matjaž Berger from Slovenia, the Croatian researcher and activist Vesna Kesić as well as distinguished cultural figures from Moscow, e.g. the curator Viktor Misiano and the philosopher Valery Podoroga). They discussed the influence of art developed in former Yugoslavia and the former Soviet Union during the 1980s. NSK Embassy Moscow was followed by numerous manifestations of the NSK State in the form of the so-called embassies and consulates. They were organized at private and public venues such as theatres (the Volksbühne in Berlin, 1993), a hotel room (NSK Consulate Florence, 1993), art exhibition venues (Venice Biennial Pavilion, 1993 and 2017, House of World Cultures in Berlin, 2010), museums (the Museum of Bosnia and Herzegovina in besieged 
Sarajevo on the day of the Dayton Peace Agreement signing in 1995). All these events resounded topically with the social, cultural and political conditions at the chosen locations.

The shaping of the identity of the NSK State predominantly takes place through art and culture. In Althusser's terms: culture is the main ideological apparatus of the NSK State. It can be argued that it rests on the same foundations as the state of Slovenia: a close and inextricable connection between the identity of its citizens and culture. Integrated into various state formations throughout its history (until the founding of Slovenia in 1991), the Slovenian nation established its identity on culture. In the opinion of many (especially leftist-oriented) intellectuals, this is an ideological interpretation of the existence of a two-million nation in the territory exposed to strategic and distinct geopolitical ambitions at the crossroads of Slavic, Germanic and Romanic cultures. An in-depth analysis of the historical facts and the relationship with their ideological interpretations was made by the philosopher Mladen Dolar (his study was published in a book on the ideology of Sloveneness-the Slovenian language, literature and culture (Ideologije o slovenskem jeziku, literaturi in kulturi, 2012). He states:

If we look at Slovenian history, it quickly becomes obvious that Sloveneness survived the last thousand years precisely due to its reliance on culture rather than due to its political, economic or military power; that culture filled the gap created by the lack and weakness of these other powers, and became a centre around which the roots of political, economic and other programmes were able to form and establish themselves. (Dolar 64)

According to Dolar, this does not mean that culture only had the role of defender of the Slovenian national identity, but especially that of its constant critic: it defended and preserved its culture by constantly questioning the existing criteria for defining what is Slovenian and what foreign, and shifting them to new levels (66-67). The NSK collective can undoubtedly be counted among the artists and groups who provocatively played around with these issues.

In the 26 years of the NSK State's existence, the connecting of its artistic activities with state and citizen practices caused plenty of witty ambiguity and misunderstandings. The modality of the social relations established by this transnational state inevitably results in ambiguity. This is a central trait of liminal entities since "this condition and these persons elude or slip through the network of classifications that normally locate states and positions in cultural space" (Turner 95). The misunderstandings are predominantly caused by the NSK citizenship issue. The NSK artists created a new concept of citizenship, one deviating from the conventional understanding of nation state citizenship, which relies on the "principle of the inscription of nativity and the trinity of state/nation/territory which is based on it" (Agamben 118). This was stated by Giorgio Agamben, who problematizes the European nation state model. It is based on the presupposition that a person's birth in a certain territory also endows them with the citizenship of that state. At a time when Europe faces waves of refugees, and when the current way of life in the EU and elsewhere in the globalized world has given rise to an increasingly diasporic mode of existence and the demand for a new concept of citizenship, Agamben's text "We Refugees" (written in 1993) again proves topical. Agamben proposes the principle of extraterritorality or aterritoriality as a basis for shaping the space and sociopolitical relations that would suit the growing number of non-citizen residents who live outside their nation states and do not wish to be repatriated. This would mean a restructuring of the space and a shaping of political communities that would reside on the same location and whose individuals would be able to belong to several communities at the same time, constantly "in exodus one into the other" (118). "This space would not coincide with any homogeneous national territory, nor with their topographical sum, but would act on these territories, making holes in them and dividing them topologically like in a Leiden jar or in a Moebius strip, where exterior and interior are indeterminate" (ibid.). Agamben notes that spaces reshaped in this manner would enable European cities to discover the ancient vocation of cities as "cities of the world." Herein, the essence of the NSK State can be recognized. Its manifestations in the form of embassies and consulates pierce through the geopolitical space of nation states, in which the locations of the NSK's artistic and other activities enable us to catch a glimpse of the possibility of their transformation into "cities of the world."

Through the years and experiences generated with the use of NSK passports, the territory of the NSK State has continued to expand. This is also due to the growing artistic production of the NSK: its artistic projects have been joined by events held by its citizens. Post 2000, the NSK State citizens latter started organizing artistic and other cultural-political events upon their own initiative and following their NSK role models in the process. The understanding of the NSK State as imagined community has changed as well. Today, it has been expanded onto the imaginary worlds and physical spaces of individual NSK citizens. This is evident from the following example. Over the years, the interest in NSK 
passports has grown to a remarkable degree, not only among artists (especially admirers of the NSK collective), but also among people who are not active in the arts at all. This has given rise to numerous questions, which is why the NSK Information Centre prepared a FAQ (published on the English version of the NSK State website). One such question is the following: "Can I enter the NSK State?" The answer is quite clear: "The NSK State has no physical territory. You 'enter' the NSK State by receiving your Passport, and wherever you are you already are also in the NSK State" ("Frequently").

The demand for NSK State passports has given rise to intriguing clashes at the intersection of the social, the cultural and the political. NSK State passports look like real-life passports (those of the Republic of Slovenia) and are even printed at the same printing house as Slovenian passports. Although they are not legally valid documents and only have a symbolic value, they have been used for crossing borders of states. This took place in the chaos of the war in Bosnia and Herzegovina, when NSK State passports were mistaken for valid documents and enabled their holders, Bosnians from Sarajevo, to cross international borders (Arns, Avantgarda 99). A decade later, in 2006, there was a huge upsurge in the demand for NSK passports among Africans, mainly Nigerians; they represent the largest single group of NSK citizens, as many as 25\% (Arns, "The Nigerian" 92). The amount of passport applications from Africa increased to such an extent that this caused problems for Slovenian authorities. The Ministry of Foreign Affairs of the Republic of Slovenia published a warning on its website that NSK State passports do not give their holders the right to reside in the Republic of Slovenia. Entitled "Important message," this notification was also re-published as a special tab on the NSK collective website (NSK State Info.). The "Frequently asked questions" tab clearly defines the relation of the NSK State to the territories, legal status and citizenships of other states (Slovenia, the EU and African countries). It explains that:

The NSK State has never had permanently operating embassies in physical space. We do not issue valid travelling or working visas and we do not send invitation letters. Symbolic visas have been issued in the past only on occasions of some NSK art events, exhibitions and concerts. Neither does the NSK State or the NSK Information Centre offer any jobs, nor can we assist you in that matter. ("Frequently")

Nevertheless, the number of applications for NSK passports from Nigeria did not diminish. Some people even claimed to have visited the NSK State. This was pointed out by an anonymous visitor of a panel discussion at the Towards a Double Consciousness: NSK Passport Project, an event that took place in July 2010 at the Centre of Contemporary Art in Lagos (and consisted of lectures, screenings and panel discussions). "'A friend of mine,' said a member of the audience, 'has a friend who knows somebody who has already been there. He said that it is a beautiful country'" (Arns, "The Nigerian" 95). After the NSK artists and researchers had just presented the The NSK State in Time artistic project, such a statement was shattering, but not surprising. According to Eda Čufer, a dramaturge and a founding member of the NSK who participated in the conceptualization of their state, the NSK State has the ability to provide a point of identification for those who reject "the cage of national culture" and "to generate a sense of disquiet" (quoted in McGrady 110). Her statement turned out to be quite on point. Similarly, Alexei Monroe confirms that numerous NSK State passport holders have indicated that the citizenship of "the state in time" gives them more satisfaction than their "actual" national status as the latter is frequently connected with the prevalence of a certain ethnic group or ideology that is perceived as threatening or exclusive (Interrogation 318). The liminal realm of the NSK State has established a utopian political space that possesses the power of transcending the ideological, physical and economic limitations of existing societies.

Whenever the NSK State produced real effects that could have actually changed the state of affairs, however, NSK artists consistently insisted on the convention on the autonomy of art-i.e. on art as a field of autonomy that indeed exists in the social field but is separate or distanced from it at the same time. When the project gave rise to effects that could have had an impact on the policies of existing countries, the artists prevented this "excess" from taking place. This was a reproach by Jože Barši in one of the rare essays that, in addition to praise, also critique the NSK State: "An obscure formalism that tries to stop the possibility of an event, of the excessive-the risk taking, the prerequisite for placing the whole project in the book of good deeds" (Barši, "NSK"). While the use of NSK State passports in the war in Bosnia and Herzegovina was an excess met with approval (also because it remained hidden from the eyes of the authorities), in the case of Nigerians, the artists themselves prevented the possibility of the passports being used as documents for crossing the border of Slovenia and the EU, in accordance with the Slovenian authorities. They thus impeded the real effects of their artistic project in advance. Although they sought to influence real life with their works (cf. their interview on 'real time projects' in: Arns, Avantgarda 99) and conceived the NSK State with the aim of leaving the autonomy of art and entering real life, they prevented that from happening at least till 2017. Even harsher criticism 
of the NSK State was expressed by Marina Gržinić and Jasmina Založnik in their joint presentation at the conference "NSK from Kapital to Capital," which accompanied the first retrospective exhibition of the works by the NSK collective in 2015 at the Modern Gallery in Ljubljana. They criticized the hegemonic form of the exhibition itself within the institutional modes of historicization of the artworks by the NSK collective. The two theorists "focused for the most part on NSK's State in Time project as a way to address how globalization has only diminished borders for the flow of capital. The biopolitical welfare state, they argued, has now transformed into the necropolitical state, a position that the recent refugee crisis in Europe makes all too clear" (Aikens, "Aesthetics"). This report can be found on the website of the Modern Gallery, which organized the exhibition and the conference, but not a recording of their presentation (with 7 out of 11 presentations published online). Perhaps it was precisely the reproach that The NSK State does not reflect current political events in the world, such as the refugee crisis, that led to the concept of the participation of the NSK State two years later at the Venice Biennale. It was then that artists apparently decided to step out of the world of art into the world of politics.

In 2017, the participation in the Venice Biennale revealed a new dimension in the operating of the NSK State. It was its most far-reaching, largest and most complex appearance so far: it attempted to connect the world of art and the world of politics by letting the utopian political space of its operation be used by humanitarian organizations in order to make an impact on society at large. It first participated in the Venice Biennale in 1993. At that time, The NSK State in Time artistic project was presented at the pavilion of the Republic of Slovenia; in other words, the Slovenian state was represented by the NSK State. In 2017, however, the NSK State was no longer part of the Slovenian pavilion, but hired its own in order to present the artistic production of NSK citizens. This was by all means a precedent in the history of the Venice Biennale as a nationally conceptualized artistic event at which countries of the world present their visual arts production at pavilions. The NSK press release notably stated that the pavilion "does not stand in opposition to the national structure of the Venice Biennale" ("NSK State Pavilion"). This statement can sooner be interpreted as a critique and warning of the obsolete concept of this eminent visual arts event that proves anachronistic in the globalized world, governed by transnational connections.

The series of events at the NSK State's pavilion focused on the theme of migration. The NSK visual arts group IRWIN, the commissioners of the pavilion, entrusted Zdenka Badovinac and Charles Esche with the curation. In order to rethink the concept of the state and propose a new citizenship model suitable for the current situation in the world, the curators decided to collaborate with individuals who had experienced migration as they had "the advantage of a bifocal perspective; one that can look at two different conditions or cultures and perceive each in greater depth than could ever be possible with a single eye" (Badovinac and Esche 3). In this, the curators turned to citizens of the NSK State and invited Ahmet Oguit to design the pavilion. The preparations also included a series of workshops that took place for an entire year, with participants who came from a variety of cultural, ideological, economic and generational backgrounds. The exchange of experience and the debates on the borders dividing the world of art and the world of politics took place with "the aim of creating a model of cooperation between the social and cultural spheres" and provide "a better understanding of migratory fluxes flows" (Ambrožič 10).

The motto and political context of the NSK State's pavilion was provided by the essay entitled "Apology for Modernity" (written in collaboration with the political philosopher Tomaž Mastnak). It was an apology of the NSK State to all refugees for their suffering and misery caused by Western liberal governments by violating the borders and destroying states from Afghanistan to Libya. The essay was written in the name of NSK citizens, who "take the burden of moral responsibility and guilt" upon themselves since they are "all complicit in the crimes our elected and unelected leaders have committed or assisted in the regions from which the refugees flee" ("An Apology" 1). The message is clear: "The state is the basic condition for individuals' moral and political life, for their freedom. In today's world, a human being is nothing without the state" (ibid.). The opinion of the citizens on this message was sought by means of a poll, in which $85.5 \%$ of NSK citizens agreed with the message, $9 \%$ were against it and $4.5 \%$ were undefined. The poll was made on a sample of 1,500 citizens. One of the reasons for disagreement was stated by the NSK diplomat Avi Pitchon, who recognized this political statement as taking part in "the current zeitgeist 'artivism' prevalent in biennales," which shifts the NSK State from art to politics, turning it "from a mischievous, trickster fairy to an obedient, tame beauty queen" and assimilating it among other political entities (Pitchon). This lucid comment on the effects produced by the liminal position of the NSK State in the social field points at the ambiguity of the line between the cultural and social fields as well as at the fact that the search for the right balance in shaping and expressing subversive artistic strategies takes a tremendous amount of resourcefulness. The NSK's "Apology for Modernity" results from an in-depth reflection on the causes and political 
circumstances behind the refugee wave across the world. This strengthened the awareness of the fact that a new model of the state and citizenship needs to be established in order to guarantee safety, the prerequisite for anyone's free agency.

In a quarter of a century of the NSK State's operation, the stance of the NSK collective towards the concept of the state has seen a radical transformation. In the early 1990s, when it was marked by a liberal leftist stance, "the State appeared as the original source of Evil, as a living dead sponging off the body of the community. The repressive, particularly ideological machinery of the State was presented as the process of supervising and maintaining discipline, as armour shaping the health body of the community" (Žižek 8). This picturesque description was made by Slavoj Žižek-an NSK State citizen and a member of the NSK department of philosophy-in an essay that accompanied the presentation of the NSK State at the Venice Biennale in 1993. At that time, the utopian perspective was focused on the abolition of the nation state and its immersion into the community. In 1993, "utopian energy is no longer directed towards a stateless community, but towards a state without a nation, a state which would no longer be founded on an ethnic community and its territory" (ibid.). Accordingly, the NSK offered a new concept of a transnational state, an alternative to nation states and the European Union (founded with the signing of the Maastricht Treaty in 1992), and invented an effective artistic strategy of subverting the then prevailing ideology of transnational idealism. As Žižek claimed in 1993, contemporary subversive art needed to be a state art in the service of a still-nonexistent state. The concept of the nation state was marked by a negative connotation at that time and the concept of transnational statehood was regarded as too idealistic by leftists. 25 years later, the confrontation with the refugee crisis led to completely different findings. In his Courage of Hopelessness lecture, which opened the NSK State pavilion at the Venice Biennale in 2015, Slavoj Zižek argued for transnational structures because, in his opinion, they are the only ones able to tackle burning issues such as migration. He stated that the key to solving the refugee crisis in Europe does not lie in the organization of humanitarian aid (although the aid is essential and much needed), but in restructuring the global socio-political field in a way that will bring the war in Syria to an end and consequently stop the refugee waves.

The NSK State pavilion also featured a room called New Symbolic Disorder (as the situation in the world could be described), with an installation exhibiting the opinions of 100 invited NSK citizens, migrants (who came to Europe from non-European countries), and stateless individuals, who discussed the bright and dark aspects of European historical, political and cultural heritage. The opinions were collected by means of a poll consisting of the following questions: what do you want to take with you from European heritage and from the heritage of your own country (as you understand it) in order to help build a new and better world? What do you want to forget or remove from European heritage and from the heritage of your own country (as you understand it) in order to avoid repeating the mistakes of the past? (El-Hassan 13). The answers provided a reflection on how to shape transnational communities and a vision of a new state paradigm in currently fragmented Europe (cf. the answers by Róza El-Hassan in her essay "Whom Shall We Ask for Amnesty?").

At the NSK passport office at the pavilion, anyone interested in NSK passports was issued one by migrants who were aided by NSK officers. In Venice in 2017, the curators and NSK artists gave the NSK State over to be operated by its citizens, migrants and stateless individuals while attempting make visitors reflect on the significance of the state and the citizenship status, and (by means of an architecturally designed installation by Ahmet Ögüt) place them into a situation offering an experience of the Kafkaesque dimension of red tape procedures faced by numerous asylum seekers across the world. Participating in the realization of the artworks in the NSK pavilion was Claudio Donadel, a specialist in migration politics, who recognized the NSK State in Time project at the Venice Biennale as a suitable public space for presenting a transnational "model of widespread territorial reception for applicants and holders of international and humanitarian protection in EU countries," which he invented based on years of experience that Italian civil society have with asylum seekers (Donadel 11). The series of carefully organized events in Venice actually managed to connect the cultural and social fields. When founding the NSK State back in 1992, the NSK artists could probably not imagine their conceptual project growing into such a propulsive communitas.

The NSK State did not only develop into a far-reaching art project with impacts on society at large, but also gave rise to a transnational community of artists positioning themselves on the art market. Already in the mid-1980s, NSK fans started to create "pseudo or meta-NSK actions and objects" (Monroe, "NSK" 23). Inspired by NSK artworks, they develop their own ideas while relying on NSK aesthetics as an inevitable and defining role model. In the course of time, the number of their artworks increased to such a degree that Alexei Monroe invented a special term for them: NSK Volk art. In this, Monroe relied on the concept of "folk art" as used at the intersection of popular culture and anthropology by the British artists and curators Jeremy Deller and Alan Kane. The spelling of the word "folk" as "Volk" 
refers to the Volk album by the Laibach music group (consisting of songs inspired by national anthems). Monroe defined NSK Volk art as "un-authorised and unpredictable works and actions made in response to NSK, which are produced primarily (but not exclusively) by NSK citizens" (Monroe, "NSK" 24). NSK Volk artists present their artworks in the scope of artistic institutions across the world, and, since 2014, at NSK State Volk Art Biennales (the first one took place in Leipzig in Germany, the second at Burren College of Art in Ireland, and the third one in Trbovlje in Slovenia). The most far-reaching, however, was the presentation of NSK Volk art at the First NSK Citizens' Congress, organized at the Haus der Kulturen der Welt contemporary arts center in Berlin. Adopted in Berlin, a declaration on further development of the NSK State announced several novelties, including an initiative to develop a new and diverse NSK symbolism. Although springing from a variety of cultural backgrounds and nation states all over the world, NSK Volk artists paradoxically create "monolith" art, which more or less remains within the set conceptual and aesthetic parameters of the NSK collective. The need to venture beyond the established course, which was expressed by NSK citizens and Volk artists in Berlin, was also met with approval by the Neue Slowenische Kunst collective.

The identity of the post-territorial and transnational NSK State is based on culture. While presenting artistic activities as citizenship practices, the NSK collective appropriates procedures reserved for state authorities. While declaratively renouncing "the cage of national culture," it introduces its own state. In this, it offers a concept of a global state alternative to the model of the nation state and the EU, and offers a new concept of transnational citizenship. At the same time, their artistic activism and politically engaged social experiment turns out to be an effective strategy for promoting their art. This is yet another paradox trait of their activities, already inscribed in their own motto: "Art is fanaticism that demands diplomacy" ("The NSK State").

Acknowledgement

The author acknowledges the financial support from the Slovenian Research Agency (research core funding No. P60376).

\section{Works cited}

"An Apology for Modernity." NSK State Pavilion - 57th Venice Biennale 2017, 11 May - 15 July 2017, NSK State Pavilion Newspaper, p. 1. https://nsk-state-pavilion.net/wp-content/uploads/2018/03/Newspaper-final-26.pdf. Accessed 30 August 2020.

Agamben, Giorgio. "We Refugees." Symposium: a Quarterly Journal in Modern Literatures, vol. 49, no. 2, 1995, pp. 114-119, $\quad$ https://thehubedu-production.s3.amazonaws.com/uploads/1836/1e788430-c11e-4036-82515406847cd504/AgambenWeRefugees.pdf. Accessed 30 August 2020.

Aikens, Nick. "Aestaetics of the State? A report on the conference NSK from Kapital to Capital at Moderna galerija, Ljubljana." 29 October 2015, https://www.internationaleonline.org/research/alter institutionality/42 aesthetics of the state a report on $t$ he conference nsk from kapital to capital at moderna galerija ljubljana/. Accessed 30 August 2020.

Ambrožič, Mara. "Notes on methodology and structure of symposiums / workshops." NSK State Pavilion - 57th Venice Biennale 2017, 11 May - 15 July 2017, NSK State Pavilion Newspaper, p. 10, https://nsk-state-pavilion.net/wpcontent/uploads/2018/03/Newspaper-final-26.pdf. Accessed 30 August 2020.

Anderson, Benedict. Imagined Communities. Reflections on the Origin and Spread of Nationalism. Verso, 2006.

Arns, Inke. Avantgarda v vzvratnem ogledalu (The Avant-garde in Rearview Mirror). Maska, 2006.

---. "The Nigerian Connection: On NSK Passports as Escape and Entry Vehicles." State in Time, edited by Irwin, Minor Compositions and Dolenjski muzej, 2014, pp. 91-96.

---. "Mobile States/Shifting Borders/Moving Entities. The Slovenian Artists' Collective Neue Slowenische Kunst (NSK)." NSK from Kapital to Capital. Neue Slowenische Kunst - An Event of the Final Decade of Yugoslavia, edited by Zdenka Badovinac, Eda Čufer, and Anthony Gardner, Moderna galerija and MIT Press, 2015, pp $222-232$.

Badovinac, Zdenka and Charles Esche. "NSK State in Time Pavilion Bienale di Venezia 2017." NSK State Pavilion 57th Venice Biennale 2017, 11 May - 15 July 2017, NSK State Pavilion Newspaper, p. 3. https://nsk-statepavilion.net/wp-content/uploads/2018/03/Newspaper-final-26.pdf. Accessed 30 August 2020.

Barši, Jože. Irwin: "NSK Država v času (detajl - Nigerijci)" (NSK State in Time - Nigerians). 30 October 2011, http://jozebarsi.blogspot.com/2011/10/irwin-nsk-drzava-v-casu-detajl.html. Accessed 30 August 2020.

"Cari amici soldati, i tempi della pace sono passati! (Thesis for the NSK Pavilion)." Padiglione NSK - Irwin, edited by Igor Zabel, Moderna galerija, 1993, pp. 12-13.

Čufer, Eda \& IRWIN. "Concepts and Relations." IRWIN: Zemljopis vremena / Geography of time (Galerija Dante Marino Cettina Umag, 10. 9. - 7. 10. 1994), Galerija Dante Marino Cettina, 1994, pp. 47-49.

---. "NSK State in Time." NSK from Kapital to Capital. Neue Slowenische Kunst - An Event of the Final Decade of Yugoslavia, edited by Zdenka Badovinac, Eda Cufer and Anthony Gardner, Moderna galerija and MIT Press, 2015, p. 501. 
Dolar, Mladen. "Ideologija in slovenstvo" (Ideology and Sloveneness). Ideologije $v$ slovenskem jeziku, literaturi in kulturi: zbornik predavanj, edited by Aleksander Bjelčević, Znanstvena založba Filozofske fakultete, 2012, pp. 62-67.

Donadel, Claudio. "Beyond Borders." NSK State Pavilion - 57th Venice Biennale 2017, 11 May - 15 July 2017 , NSK State Pavilion Newspaper, p. 11, https://nsk-state-pavilion.net/wp-content/uploads/2018/03/Newspaper-final26.pdf. Accessed 30 August 2020.

El-Hassan, Róza. "Whom Shall We Ask for Amnesty?" NSK State Pavilion - 57th Venice Biennale 2017,11 May 15 July 2017, NSK State Pavilion Newspaper, p. 13, https://nsk-state-pavilion.net/wpcontent/uploads/2018/03/Newspaper-final-26.pdf. Accessed 30 August 2020.

"Frequently Asked Questions." https://passport.nsk.si/en/faq. Accessed 30 August 2020.

McGrady, Conor. "The 'First NSK Citizens' Congress' in Berlin: A Summary." State in Time, edited by Irwin, Minor Compositions and Dolenjski muzej, 2014, pp. 109-116.

Intihar Ferjan, Jana. "Chronology of Neue Slowenische Kunst and its Groups 1980-1992." NSK from Kapital to Capital. Neue Slowenische Kunst - An Event of the Final Decade of Yugoslavia, edited by Zdenka Badovinac, Eda Cufer, and Anthony Gardner, Moderna galerija and MIT Press, 2015, pp. 506- 525.

Monroe, Alexei. Interrogation machine: Laibach and NSK (Short Circuits). The MIT Press, 2005.

---. "NSK: The State which Ran Away with Itself ..." State in Time, edited by Irwin, Minor Compositions and Dolenjski muzej, 2014, pp. 21-27.

Pitchon, Avi. "A Confirmation of Civil Unrest." Published 11 May 2017, http://times.nskstate.com/a-confirmation-of-civil-unrest/. Accessed 30 August 2020.

NSK State Info. Center. "Important Message." The Official Pages of the NSK State Passport Office, https://passport.nsk.si/en/important message. Accessed 30 August 2020.

"NSK State Pavilion - 57th Venice Biennale." NSK State Pavilion, 2017, https://nsk-state-pavilion.net/about/. Accessed 30 August 2020.

"The NSK State." The Official Pages of the NSK State Passport Office, https://passport.nsk.si/en/about us. Accessed 30 August 2020.

"The Official Pages of the NSK State Passport Office." https://passport.nsk.si/en/. Accessed 30 August 2020.

Turner, Victor. "Liminality and Communitas." The Ritual Process. Structure and Anti-Structure, Cornell UP, 1966, pp. 94-130.

Westerman, Jonah. "Contesting Utopias: Individual Collectivity and Temporal Hybridity in the NSK State in Time." State in Time, edited by Irwin, Minor Compositions and Dolenjski muzej, 2014, pp. 159-169.

Žižek, Slavoj. "Es gibt keinen Staat in Europa." NSK State Pavilion - 57th Venice Biennale 2017,11 May - 15 July 2017, NSK State Pavilion Newspaper, p. 8, https://nsk-state-pavilion.net/wpcontent/uploads/2018/03/Newspaper-final-26.pdf. Accessed 30 August 2020.

Author's profile: Barbara Orel is Professor of the Performing Arts and head of the research group of the Academy of Theatre, Radio, Film and Television at the University of Ljubljana. Her main areas of research are experimental theatre, avant-garde movements and performance across disciplines. Her publications include the edited collection Uprizoritvene umetnosti, migracije, politika: slovensko gledališče kot sooblikovalec medkulturnih izmenjav (Performing Arts, Migration, Politics: Slovenian Theatre as an Agent of Intercultural Exchange) (Ljubljana University Press, Faculty of Arts, 2017) and contributions to the books Playing Culture: Conventions and Extensions of Performance (Rodopi, 2014), International Performance Research Pedagogies: Towards an Unconditional Discipline? (Palgrave Macmillan, 2017) and Theatre in the Context of the Yugoslav Wars (Palgrave Macmillan, 2018). Email: <barbara.orel@agrft.uni-lj.si> 